A) Eski Acıgöl Lake (Turkey)

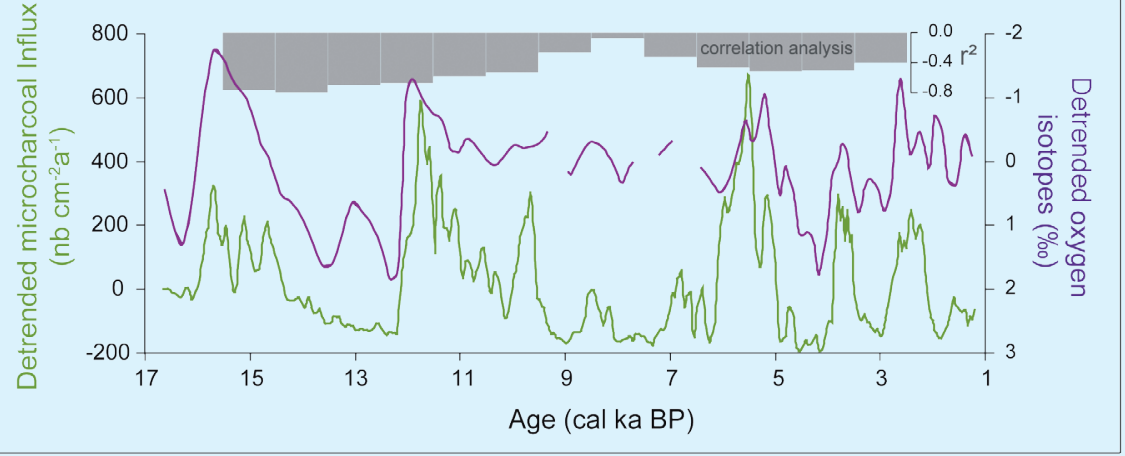

B) Lago dell'Accesa (Italy)

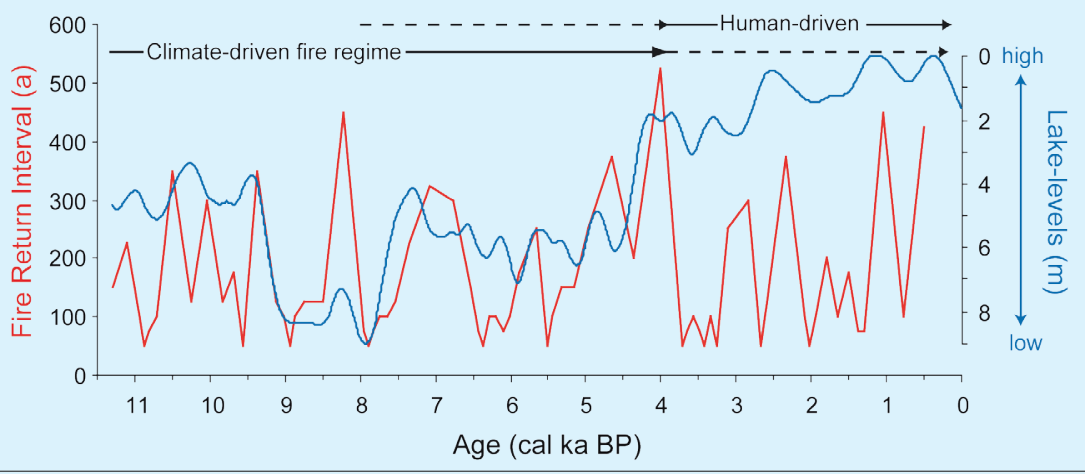

Figure 2: $\boldsymbol{A}$ ) Detrended microscopic charcoal (green line) and oxygen isotope record (purple line) for Eski Acıöl Lake (Turkey). Correlation analysis (gray bars) shows statistically significant correlations between microscopic charcoal influx (particles $\mathrm{cm}^{-2} \mathrm{a}^{-1}$ ) and $\delta^{18} \mathrm{O}(\%)$ for most of the record (modified from Turner et al., 2008); B) Lago dell'Accesa (Tuscany, Italy) lake-level fluctuations (blue line; modified from Magny et al., 2007) and the fire-return interval (red line) reconstructed from fire-event detection based on sedimentary macroscopic charcoal (modified from Vannière et al., 2008). Peaks in the fire-return interval curve correspond with high lake-level stands before 4 cal ka BP. across the Mediterranean (Carrión et al., 2003, 2007; Sadori et al., 2008).

\section{Conclusion}

The paleofire record from the Mediterranean is paradoxical. Climatic variations have certainly acted as one of the main pacemakers of fire regimes, particularly in the first half of the Holocene. Under different climate conditions (e.g., seasonality of precipitation), the southern and northern Mediterranean may have been terranean Europe. Even apparently wellestablished relationships, such as evergreen oaks being favored by fire, turn out to be wrong when viewed over decadal to centennial timescales. These complex long-term responses are significant in the context of increasing aridity and warming, as well as major regional land-use changes linked to agricultural and tourism development around the Mediterranean Sea. Understanding them will help us to better manage and preserve one of the most fireprone regions of the world, characterized by extraordinary plant diversity.

\section{Data}

The data are submitted to the Global Palaeofire Working Group Database (http://www.gpwg. org) and are available by contacting B. Vannière (boris.vanniere@univ-fcomte.fr)

\section{Acknowledgements}

We are greatly indebted to M. Magny, M. Power, W. Tinner and R. Turner who have contributed to these results and for enriching discussions about paleofire. Many thanks also to all contributors to the Mediterranean part of the Global Charcoal Database.

\section{References}

Colombaroli, D., Tinner, W., van Leeuwen, J.F.N., Noti, R., Vescovi, E., Vannière, B., Magny, M., Schmidt, R. and Bugmann, H., 2009: Response of broad-leaved evergreen Mediterranean forest vegetation to fire disturbance during the Holocene: insights from the peri-Adriatic region, Journal of Biogeography, 36: 314-326.

Colombaroli, D., Vannière, B., Chapron, E., Magny, M. and Tinner, W. 2008: Fire-vegetation interactions during the Mesolithic-Neolithic transition at Lago dell'Accesa, Tuscany, Italy, The Holocene, 18: 679-692.

Turner, R., Roberts, N. and Jones, M.D., 2008: Climatic pacing of Mediterranean fire histories from lake sedimentary microcharcoal, Global and Planetary Change, 63: 317-324.

Vannière, B., et al., in press: Circum-Mediterranean fire activity and climate changes during the mid Holocene environmental transition (8500-2500 cal yr BP), The Holocene.

Vannière, B., Colombaroli, D., Chapron, E., Leroux, A., Tinner, W. and Magny, M., 2008: Climate versus human-driven fire regimes in Mediterranean landscapes: the Holocene record of Lago dell'Accesa (Tuscany, Italy), Quaternary Science Reviews, 27: 1181-1196.

\title{
Tropical fire ecology across the African continent: A paleoecological perspective
}

\author{
Daniele Colombaroli ${ }^{1,2}$ and Dirk Verschuren ${ }^{2}$ \\ 'Institute of Plant Sciences and Oeschger Center for Climate Change Research, University of Bern, Switzerland; daniele.colombaroli@ips.unibe.ch \\ 'Limnology Unit, Department of Biology, Ghent University, Belgium
}

\section{High-resolution charcoal records from African lake sediments provide new insights for longstanding research questions on fire-climate-human interactions in tropical and subtropical ecosystems.}

Every year, the tropics experience more fire than any other region in the world (Fig. 1). Tropical grassland (savannah) fires are the dominant source of carbon from biomass burning and provide more than $60 \%$ of the global total (Mouillot and Field, 2005). However, much of what is known about tropical fire ecology is based on monitoring programs started within the last decade, with highly fragmentary historical data extending only to the early $20^{\text {th }}$ century. These data do not allow us to assess whether recent trends in fire frequency and magnitude are unusual in the context of natural long-term ecosystem dynamics (Gillson and Willis, 2004).

\section{Natural or anthropogenic fire regime?}

Seventy percent of tropical and subtropical areas worldwide are considered to have ecologically degraded fire regimes (Shlisky et al., 2007). In Africa, the recent increase in fire frequency is attributed to human ecosystem disturbance associated 
with intensifying agriculture (Fig. 2; Davidson et al., 2003). For instance, in the lowland rainforests of West Africa and in moist montane forests at higher elevations in East Africa, natural fire is uncommon (Goldammer, 1990). Yet widespread clearance of natural vegetation has converted large, formerly forested areas into highly flammable grasslands (Roberts, 2000; Goldewi$j k, 2001)$. Studies of global-scale patterns in historical land use (e.g., Archibald et al., 2005) tend to assume that human impact on tropical African ecosystems was limited before 1700 AD because population densities of indigenous people were low (Goldewijk, 2001; Ramankutty and Foley, 1999). This perspective contrasts with archeological and paleoecological evidence that indicates that anthropogenic forest clearance in parts of East Africa started at least $2.5 \mathrm{ka}$ ago, in association with the introduction of iron smelting technology (Robertshaw and Taylor, 2000). Other authors suggest that humans have altered African forest ecosystems over a longer time (Willis et al., 2004). If increasing fire activity during the Holocene was indeed related to intensifying human impact (Lejju et al., 2005; Ryner et al., 2008), the timing and extent to which humans altered local ecosystems varied regionally and among ecosystems. For instance, recent studies indicate that deforestation associated with sedentary agriculture started only $\sim 0.35$ ka ago in the moist highlands of central Kenya (Lamb et al., 2003) but at least $\sim 0.8-1$ ka ago in sub-humid western Uganda (Ssemmanda et al., 2005; Russell et al., 2009). In drier environments, agricultural activity often began $\sim 0.12$ ka ago, during colonial times, yet landscapes may have been significantly modified by pastoralist cultures well before then. Detailed charcoal studies with adequate spatial coverage are needed to determine whether current fire regimes are within the range of historic variability (Willis and Birks, 2006), or whether fire frequency has increased in response to the different types and intensities of human impact associated with pastoralist and agriculturalist societies.

\section{Fire regime response \& feedback to past climate variability}

High-resolution charcoal studies have shown how fire can be a "catalyst" for climate-change effects on vegetation. For instance, moist conditions limit fire to spread in present tropical forests, but during drier periods in the past wildfire was likely more common, causing changes in ecosystem structure and degradation (e.g., Willis and Birks, 2006; Bush et al.,
2008; Fig. 2). Climate-proxy information from the sediments of East African lakes document major variations in moisture balance. For example, in the late $18^{\text {th }}$ century, an episode of severe drought completely desiccated all but one lake in the Eastern Rift Valley of Kenya, south of Lake Turkana (Verschuren, 2004; Bessems et al., 2008). In the last few millennia, centurylong periods of both significantly drier and wetter conditions than today have occurred over most of equatorial East Africa. There have also been periods (e.g., from $~ 1500$ to 1750 AD) when climate was unusually dry in the normally sub-humid western parts of the region while remaining unusually wet in semi-arid regions further east (Verschuren et al., 2000; Russell and Johnson, 2007). Research documenting the response of terrestrial ecosystems to this climate variability reveals the high sensitivity of vegetation transition zones, such as the forest/savannah ecotone, to even modest decadal-scale variations in rainfall (Lamb et al., 2003; Ngomanda et al., 2007). Additional charcoal records of high temporal resolution are needed to show how fire regimes have responded to contrasting climate trends at the regional scale (Fig. 1b).

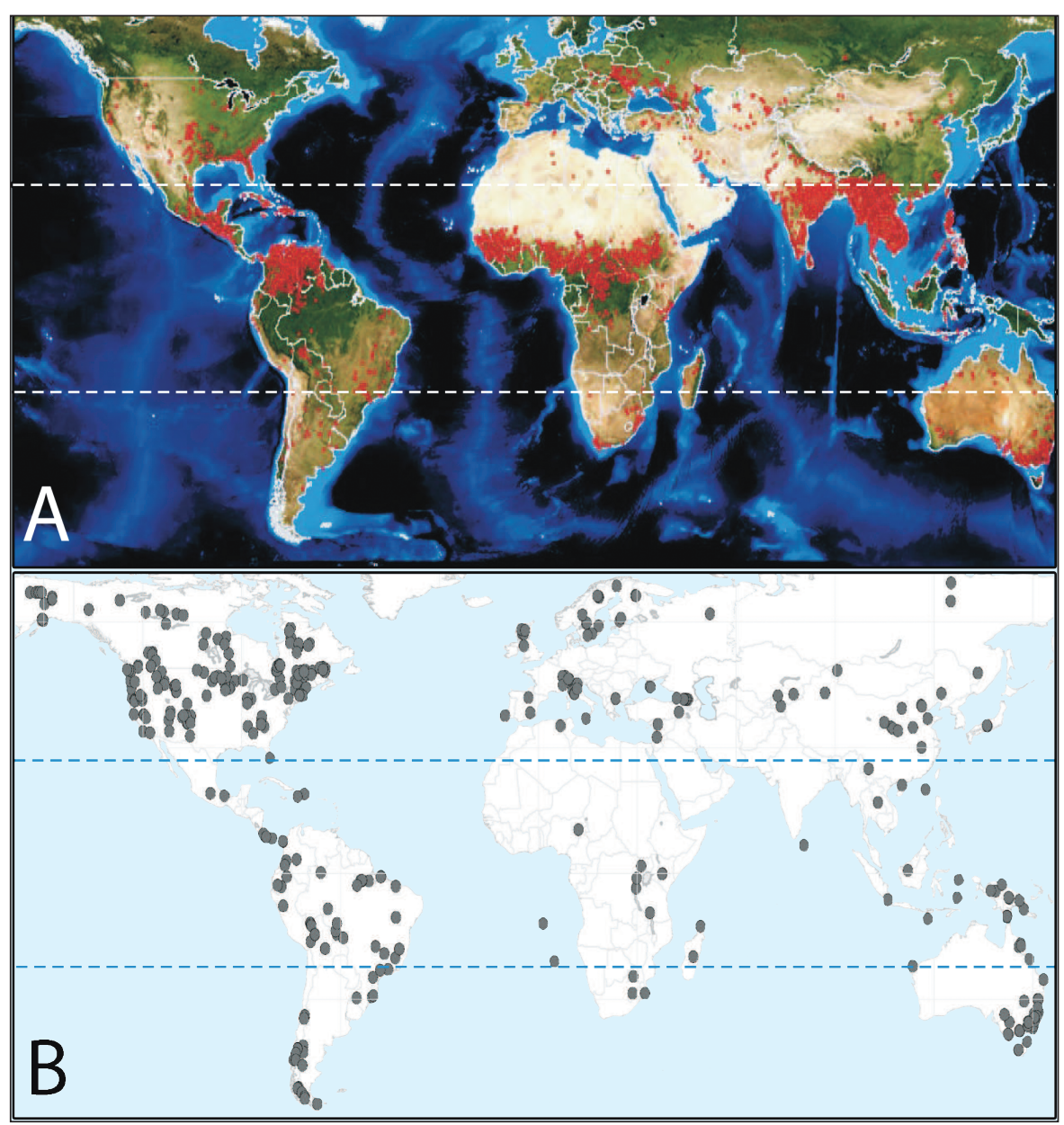

Figure 1: A) Satellite image of world fire activity detected by MODIS in the early spring of 2010 (red dots, data from Fire Information for Resource Management System FIRMS, http://maps.geog.umd.edu/firms). B) Worldwide geographical distribution of paleoecological fire-regime records currently in the Global Charcoal Database (modified from Power et al., 2008). Despite the great fire activity in tropical and subtropical ecosystems, few paleofire records are available from regions such as Africa. Dashed lines delimit the tropical region, bounded by latitudes $23.5^{\circ} \mathrm{N}$ and S. 


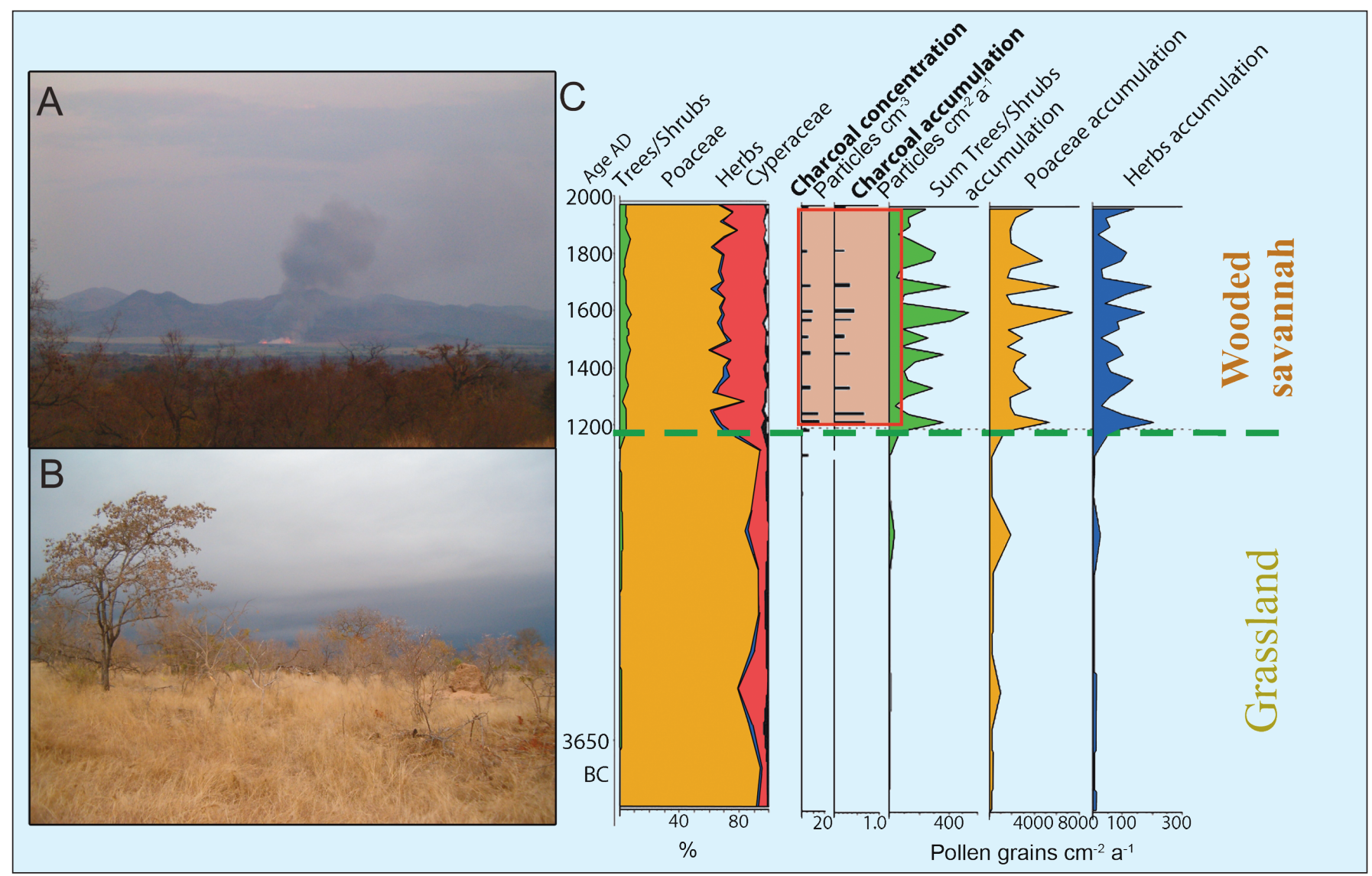

Figure 2: A) Human-set fire in a rural area close to Mozambique border. Here, fire is used to clear land for agriculture and livestock ranching. B) Wooded savannah stand in Kruger National Park (South Africa). During the dry season (Apr-Oct), most of the biomass dries, increasing the fire hazard. (Photos by D. Colombaroli). C) Pollen and charcoal record from Malahlapanga Lake (Kruger National Park) showing the transition from grassland to a fire-maintained wooded savannah after 1100 AD (modified from Gillson and Ekblom, 2009). The authors suggested that increased regional rainfall promoted biomass production (i.e., wooded savannah), allowing fire activity to increase.

on long timescales and in multiple regions to determine whether this feedback is characteristic of presently highly disturbed conditions, or whether it also occurred during natural cycles of long-term hydrological change. Paleoinformation on the resilience of tropical moist forests to occasional fire and, specifically, the rate at which rainforests recover from destructive fire would also be highly instructive for future conservation (Cochrane, 2003). New reconstructions of past fire regimes based on fossil charcoal analysis that quantify the local frequency of fire (e.g., Whitlock and Larsen, 2001; Gavin et al., 2006; Higuera et al., 2008), combined with modern calibration studies (Duffin et al., 2008), should reveal how African ecosystems respond to fire variability at decadal to century timescales.

\section{Research outlook}

Coupled atmosphere/ocean/biosphere climate models project future temperatures across tropical Africa to increase from 0.2 to $0.5^{\circ} \mathrm{C}$ per decade, and pre- cipitation in East Africa to increase during the short rainy season (Northern Hemisphere winter) and decrease during the main rainy season (Northern Hemisphere spring) (Hulme et al., 2001; IPCC, 2007). In addition, changes in the teleconnected $\mathrm{El}$ Niño/Southern Oscillation (ENSO) are projected to cause pronounced drought in some regions and increased risk of flooding in others (Wara et al., 2005). If mean annual precipitation over East Africa does increase (IPCC, 2007), its beneficial effect on forest ecosystems will likely be lost in areas with frequent anthropogenic fires and increasing demographic pressure. Insights into how Africa's forest and savannah ecosystems will respond to the multiple stressors of future global climate change requires an understanding of past ecosystem responses to large-magnitude environmental changes. Currently still very rare in Africa and elsewhere in the tropics, high-resolution paleoecological records of (pre-)historical human impact, fire and vegetation can provide such holistic information.

\section{Acknowledgements}

We thank Lindsey Gillson for useful comments and Mitchell J. Power for the global map of sites in the Global Charcoal Database. The project "Fire, climate change and human impact in tropical ecosystems: paleoecological insights from the East African region" is funded by the Swiss National Science Foundation (FNS "Ambizione" Project no. PZ00P2_126573).

\section{References}

Cochrane, M.A., 2003: Fire science for rainforests, Nature, 421: 913-919. Duffin, K.I., Gillson, L. and Willis, K.J., 2008: Testing the sensitivity of charcoal as an indicator of fire events in savanna environments: quantitative predictions of fire proximity, area and intensity, The Holocene, 18: 279-291.

Gillson, L. and Ekblom, A. 2009: Resilience and thresholds in savannas: nitrogen and fire as drivers and responders of vegetation transition, Ecosystems, 12: 1189-1203.

Sankaran, M., Hanan, N. and Scholes, R., 2005: Determinants of woody cover in African savannah, Nature, 438: 846-849.

Willis, K.J., Gillson, L. and Brncic, T.M., 2004: How "virgin" is virgin rainforest? Science, 304: 402-403.

For full references please consult:

http://www.pages-igbp.org/products/newsletters/ref2010_2.html 